\title{
HOLSAT Evaluation of International Tourist's Expectations and Experiences of Fiji as a Holiday Destination
}

\author{
Neale J. Slack \\ College of Business, Hospitality \& Tourism Studies, School of Management, Fiji National University, Suva, Fiji \\ Email: njslack@gmail.com
}

How to cite this paper: Slack, N.J. (2019) HOLSAT Evaluation of International Tourist's Expectations and Experiences of Fiji as a Holiday Destination. Theoretical Economics Letters, 9, 2418-2435. https://doi.org/10.4236/tel.2019.97153

Received: August 22, 2019

Accepted: September 27, 2019

Published: September 30, 2019

Copyright (อ 2019 by author(s) and Scientific Research Publishing Inc. This work is licensed under the Creative Commons Attribution International License (CC BY 4.0).

http://creativecommons.org/licenses/by/4.0/

\section{cc) (i) Open Access}

\begin{abstract}
The aim of this research is to investigate international tourist's expectations and experiences of Fiji as a holiday destination. This study used a modified HOLSAT questionnaire to source responses. 200 international tourists who were staying in hotels in Fiji participated in an intercept survey conducted in Nadi, Lautoka, and Suva. Descriptive and inferential statistics were employed to analyse tourist's positive and negative holiday expectations and experiences. Results indicate that most positive attribute items of a holiday met or exceeded tourist's expectations, most negative attribute items of a holiday were below tourist's expectations, and both contributed to tourist's sense of satisfaction with the holiday destination. Holiday attribute items that failed to satisfy tourists provide opportunities for further research and targeted interventions to further enhance tourist's satisfaction with Fiji as a holiday destination.
\end{abstract}

\section{Keywords}

Tourist, Holiday, Expectations, Experiences, Satisfaction

\section{Introduction}

"International travel continues to grow rapidly, securing the tourism sector as a key driver of economic development" [1]. International tourist arrivals worldwide showed strong, sustained growth between 2010 and 2016 of 4.0 percent, while in 2017 tourist arrivals worldwide reached 1.3 billion, being an annual increase of 7.0 percent. It is also projected that continued strong growth will continue into the foreseeable future, and international tourist arrivals will escalate to 1.8 billion by 2030 [2]. 
Against this backdrop, Fiji is a small island developing economy in the South Pacific Ocean, and is the second most populous Pacific island country with a population of 884,887 [3]. Tourism earnings in Fiji have continued to exponentially increase from Fiji $\$ 328.1$ million in 1992, to Fiji\$1.2 billion in 2010, and Fiji $\$ 1.8$ billion in 2016, and are the major source of foreign exchange. Driving the tourism earnings has been the doubling of tourist arrivals from 259,350 in 1991 to 792,320 in 2016 [1]. The tourism sector in Fiji also contributed to 40.4 percent of GDP in 2016 and is expected to increase to 44.9 percent by 2027. Additionally, in 2016, the tourism sector directly supported 42,500 jobs (13.0 percent of all employment) and indirectly supported 119,000 jobs (36.6\% of all employment) [2]. "While there is a growing role and importance of tourism in the Fijian economy as the key source of foreign exchange earner and employment generation, it is imperative to pay more attention to the determinants of tourism arrivals in Fiji" [1].

Notwithstanding, "positive tourist experiences are crucial for the continued success of tourist destinations around the world" [4]. Hence, it is imperative that travel market researchers identify tourist's holiday needs and wants, and tourism agencies deliver a holiday that not only sells "accommodation", but a complete "holiday" package [5], that provides tourists a memorable experience at a chosen destination [6] [7]. Be that as it may, fierce global competition among tourism agencies and destinations necessitates the need for development of a competitive strategy that targets markets and differentiates tourism destinations against other destinations, enables tourism destinations and agencies to operate more effectively than their competitors, and offers a more attractive holiday package to tourists [8].

To date, satisfaction research in tourism has tended to focus on various aspects of tourist satisfaction such as satisfaction with service quality of hotels and restaurants [9] [10], tour guides [11]; sightseeing tours [12], and cultural tours [13] [14], as opposed to satisfaction with a holiday destination [15] [16]. Also, satisfaction research in tourism has tended to be limited to popular destinations [17] [18]; hence, a dearth of studies of developing countries exists. More specifically, previous tourism research relating Fiji has investigated aspects of tourism other than satisfaction, such as the contribution of tourism to the development of Fiji [19], the impact of environment on the Fiji tourism industry [20], and the like.

Bearing in mind the mentioned shortcomings, and the dearth of holiday destination satisfaction research in tourism generally [15] [16], and in particular in Fiji, and the vital role tourism plays in Fiji [1], provide the impetus for this research to investigate the expectations and performance ("experience") aspects of Fiji as a holiday destination, as identified by international tourists.

The rest of this paper is organized as follows. In Section 2, we review customer satisfaction, its measurement, and the HOLSAT model. In Section 3, the research methodology is detailed. In Section 4, results and discussion of findings are provided. Section 5 discusses the conclusions. 


\section{Literature Review}

\subsection{Customer Satisfaction}

Customer satisfaction as suggested by [21] is a "slippery term", due to its highly subjective nature and the inconsistency in definitions that exist [22] [23]. This makes the measurement, interpretation and comparison of customer satisfaction results challenging [24] [25]. Notwithstanding, tourist satisfaction is acknowledged as a principal indicator of a destinations' performance and competitiveness [26] [27], and warrants measurement, interpretation and comparison, to inform policy makers, marketing decision makers, and tourism agencies.

Extant literature highlights that tourism satisfaction studies typically either focus on tangible, functional attributes that are readily measurable [28] [29], or on intangible, psychological aspects of satisfaction, which are more difficult to measure [30] [31]. However, functional attributes have gained more research attention compared to psychological attitudes [32]. In addition, wide ranging opinions exist as to the main attributes of a holiday that attract a tourist to a destination: scenery, hospitality, receptiveness, cost, climate, activities, entertainment and sports facilities [32]; the physiography and climate, culture and history; range and mix of activities and entertainment available, events offered, superstructure, human relationships [33]; and natural, social, historical, recreational and shopping facilities, food and shelter [34] [35].

\subsection{Measuring Customer Satisfaction}

Extant literature proposes various theories, approaches and instruments for measuring customer satisfaction [8], and more specifically for measuring the level of customer satisfaction of tourists. The main research instruments developed to analyse service quality and customer satisfaction are the Importance-Performance Analysis [36], SERVQUAL [37], SERPERF [38], and the HOLSAT holiday satisfaction [21]. The Importance-Performance Analysis uses the confirmation/disconfirmation concept [21] developed by [39] and [40], and has been criticised on the basis that empirical research suggests consumer satisfaction is a function of both expectations of performance and actual performance [36]. The SERVQUAL instrument measures the difference between customer's expectations that an excellent (ideal) service would provide and customer's perceptions of the actual service received [41], and has been widely criticised on the basis that an inbuilt bias towards dissatisfaction exists [21]. Some researchers [38] [40] suggest the removal of the expectations from the SERVQUAL and use only of the perceptions of actual performance to determine satisfaction of respondents. In line with this suggestion, the SERPERF developed by [38] measures only the service performance, and has also been criticised on the basis that "performance alone cannot give a full picture of satisfaction" [21].

Numerous researchers [42] [43] [44] [45], have used a range of instruments to measure the level of customer satisfaction (gap analysis based on expectations and perceptions of service), and applied this approach to the measurement of 
individual services of a destination, in the tourism sector [16]. Nevertheless, the approach adopted by these researchers focuses on the services delivered by a particular hotel, as opposed to assessing the overall holiday experience [16].

\subsection{The HOLSAT Model}

Considering the research instruments and approaches mentioned, and their obvious criticisms, the instrument adopted for use in this research is the HOLSAT model, because this model "overcomes some of the limitations of other models when satisfaction is measured for a destination rather than a specific service" [16]. The HOLSAT instrument addresses the multidimensional nature of tourist's satisfaction with a specific destination through a comparison of a broad range of attributes (namely the physical resort and facilities; ambience; restaurants, bars, shops and light life; transfers; heritage and culture; and accommodation) of expectation against the holiday performance ("experience") [21] [46]. However, the HOLSAT instrument does not utilise a fixed menu of attributes supposedly generic to all destinations; rather allows for customisation of attributes to best suit the particular destination under study. This flexibility in attributes addresses the concerns raised by [47] that fixed dimensions were not necessarily applicable in all destinations. Additionally, the use of both positive (favourable impressions of the destination) and negative (unfavourable impressions of the destination) attributes of a destination, is a peculiar characteristic of the HOLSAT instrument. This allows tourists to express both positive and negative aspects of a holiday [21] [46].

The HOLSAT instrument features 56 items ( 49 positive and 7 negative holiday attributes) representing the 6 categories of attributes, with tourists asked to rate their expectations before their holiday, during their holiday (performance measure 1), and after their holiday (performance measure 2), based on these items, on a 5-point Likert scale. "The scale was labelled and scored [strongly disagree $(-4)$, disagree $(-2)$, no opinion $(0)$, agree $(+2)$, strongly agree $(+4)$, and an additional box was included labelled not applicable]" [21]. Mean scores for the expectations and performance are calculated, as is the mean sum of differences between the expectations and performance, for each respondent, and for each attribute item. In order to assist interpretation of the attribute item mean scores, the attribute item numbers are plotted in a matrix and numbered data points result. To further aid interpretation, a diagonal "draw" line is provided in the matrix to indicate where perception of performance (X-axis) equals expectations ( $\mathrm{Y}$-axis). For positive attribute items, numbered data points located above the "draw" line indicate "loss", that is a loss of satisfaction, while numbered data points below the "draw" line indicate "win", that is gain in satisfaction. For negative attribute items, numbered data points located above the "draw" line indicate "win", that is gain in satisfaction, while numbered data points below the "draw" line indicate "loss", that is loss of satisfaction. The further a numbered data point is away from the "draw" line, the greater is the loss or gain of satisfac- 
tion for that specific attribute [16]. Inferential analysis (paired samples t-test) is also used to determine the probability of difference between the tourist's expectations and performance scores.

\section{Research Methodology}

\subsection{Survey Instrument}

The modified HOLSAT survey instrument utilised for this empirical study consists of two parts and comprises 41 attribute items. The first part of the questionnaire (Part A.) contains 7 demographic questions, to measure the demographic characteristics of respondents. The second part of the questionnaire comprises 31 positive and 10 negative attribute items derived from the HOLSAT survey developed by [21], and from a modified HOLSAT survey [16]. Attribute items were also modified to suit the context of the tourist destination being studied. While the HOLSAT survey groups the attribute items into the following categories: physical resort and facilities; ambience; restaurants, bars, shops and nightlife; transfers; heritage and culture; and accommodation; it is suggested that this approach tends to somewhat focus on the characteristics of the hotel [21]. Hence, in this research, the "Five A's" categorisation of attributes, as suggested by [16], was adopted: "attractions", "activities", “Amenities", "Accommodation", and "Accessibility". While this categorisation was similar to the HOLSAT developers [21] categorisation, it is suggested that a broader view of the holiday (beyond the hotel) was possible. The second part of the questionnaire requires respondents to rate each attribute item according to a five-point Likert scale. "The scale was labelled and scored [strongly disagree $(-4)$, disagree $(-2)$, no opinion (0), agree $(+2)$, strongly agree $(+4)$ ]" [21]. Respondents were asked to submit a rating for both their expectations (Part B.1.) and the performance ("experience") (Part B.2.) for each of the 41 holiday attributes items. Table 1 shows a sample sheet from the questionnaire, namely Part B.1. Expectations.

A pilot test of the modified HOLSAT survey instrument was conducted with 20 tourists in Nadi, Fiji, in October 2016, to check the usability of the instrument and to gain valuable feedback from respondents regarding the wording of the instrument. Minor wording changes were suggested and were incorporated into the questionnaire. The questionnaire was designed in English.

\subsection{Target Population, Sampling and Response}

The target population for this study was international tourists $(n=200)$ that had arrived in Fiji, and were staying in hotels. The public-intercept, self-completion questionnaire data collection occurred during December 2016 (a peak period when tourists visit Fiji), in the western division of Fiji (Nadi and Lautoka) and in the eastern division (Suva). Table 2 shows 245 tourists were intercepted, with 35 tourists declining to participate in the survey (response rate of 86.0 percent), and 10 questionnaires found to be unusable (completion rate of 95.0 percent), resulting in 200 usable questionnaires. 
Table 1. Sample sheet from the questionnaire.

\begin{tabular}{|c|c|c|c|c|c|c|}
\hline \multicolumn{7}{|c|}{$\begin{array}{l}\text { Part B.1. Expectations: Based on your expectations of the holiday, } \\
\text { please tick the appropriate box for the following statements. }\end{array}$} \\
\hline No. & Statement & $\begin{array}{l}\text { Strongly } \\
\text { Disagree }\end{array}$ & Disagree & $\begin{array}{c}\text { No } \\
\text { Opinion }\end{array}$ & Agree & $\begin{array}{l}\text { Strongly } \\
\text { Agree }\end{array}$ \\
\hline 1 & The beaches and ocean would be clean & & & & & \\
\hline 2 & Check in and check out times would be flexible & & & & & \\
\hline 3 & The resort would be clean & & & & & \\
\hline 4 & The resort would be safe and secure & & & & & \\
\hline 5 & The resort would have a variety of restaurants & & & & & \\
\hline 6 & The resort would have a variety of bars & & & & & \\
\hline 7 & The resort would have a variety of shops & & & & & \\
\hline 8 & The resort would have a variety of nightlife & & & & & \\
\hline 9 & Restaurants would be cheap & & & & & \\
\hline 10 & Bars would be cheap & & & & & \\
\hline 11 & Shops would be cheap & & & & & \\
\hline 12 & Nightlife would be cheap & & & & & \\
\hline 13 & Hotel meals would be of high quality & & & & & \\
\hline 14 & There would be a lack of public toilet facilities & & & & & \\
\hline 15 & In-flight service would be high quality & & & & & \\
\hline 16 & $\begin{array}{l}\text { The arrival airport would be modern and } \\
\text { efficient }\end{array}$ & & & & & \\
\hline 17 & $\begin{array}{l}\text { Transfer vehicles would be on-time and air } \\
\text { conditioned }\end{array}$ & & & & & \\
\hline 18 & $\begin{array}{l}\text { I would have difficulty obtaining cash from my } \\
\text { credit card or ATM }\end{array}$ & & & & & \\
\hline 19 & I would have to be careful what I eat and drink & & & & & \\
\hline 20 & Changing money would be difficult & & & & & \\
\hline 21 & $\begin{array}{l}\text { Immigration and customs clearance would be } \\
\text { slow and inefficient }\end{array}$ & & & & & \\
\hline 22 & I would be able to sample local food and drink & & & & & \\
\hline 23 & Water sports would be available & & & & & \\
\hline 24 & $\begin{array}{l}\text { I would be able to experience traditional Fijian } \\
\text { singing and dancing }\end{array}$ & & & & & \\
\hline 25 & I would be able to shop in local markets & & & & & \\
\hline 26 & I would be able to buy cheap Fijian artefacts & & & & & \\
\hline 27 & I would be able to experience an island cruise & & & & & \\
\hline 28 & $\begin{array}{l}\text { There would be many beggars and street } \\
\text { vendors }\end{array}$ & & & & & \\
\hline 29 & Hotel staff would be friendly & & & & & \\
\hline 30 & The room would be quiet & & & & & \\
\hline 31 & The room would have a good view & & & & & \\
\hline
\end{tabular}




\section{Continued}

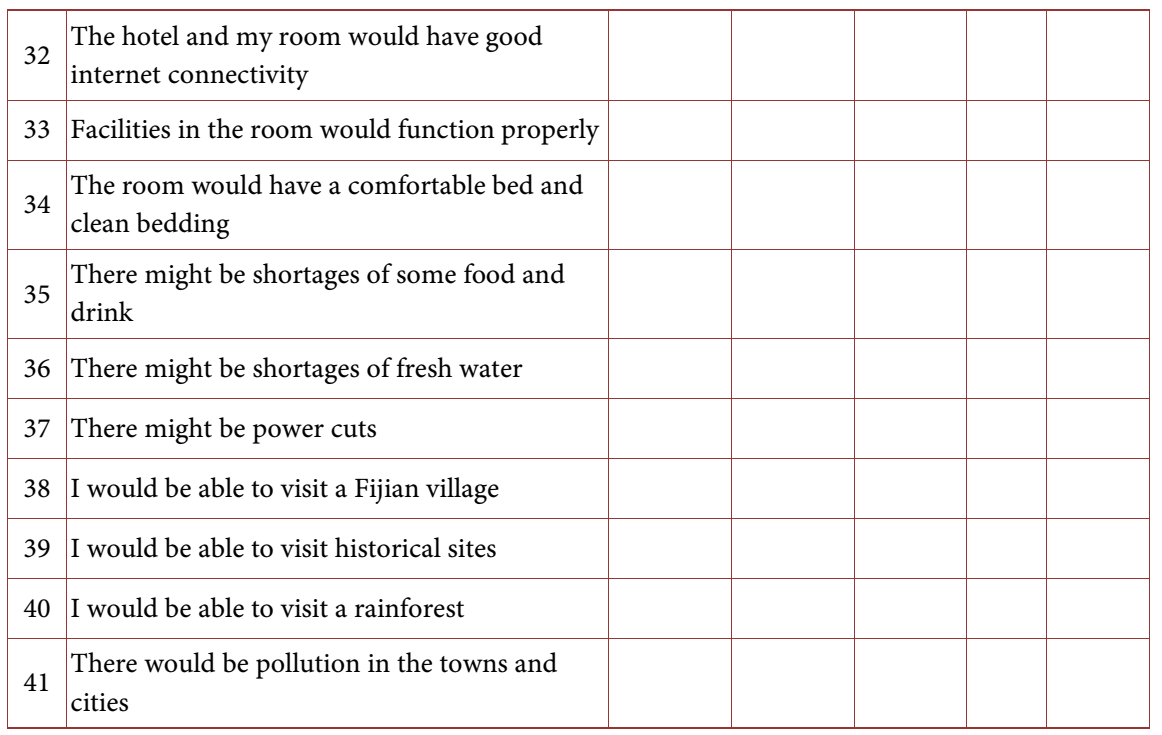

Table 2. Response and completion rate.

\begin{tabular}{ccccccc}
\hline $\begin{array}{c}\text { No. of } \\
\text { Tourists } \\
\text { Intercepted }\end{array}$ & $\begin{array}{c}\text { No. of Tourists } \\
\text { Declined to } \\
\text { Participate }\end{array}$ & $\begin{array}{c}\text { No. of } \\
\text { Respondents }\end{array}$ & $\begin{array}{c}\text { Response } \\
\text { Rate }\end{array}$ & $\begin{array}{c}\text { No. of } \\
\text { Unusable } \\
\text { Questionnaires }\end{array}$ & $\begin{array}{c}\text { No. of } \\
\text { Usable } \\
\text { Quionnaires }\end{array}$ & $\begin{array}{c}\text { Completion } \\
\text { Rate }\end{array}$ \\
\hline 245 & 35 & 210 & $86 \%$ & 10 & 200 & $95 \%$ \\
\hline
\end{tabular}

\section{Results and Discussion}

Statistical Package for the Social Sciences version 25 was used to analyse the data. Reliability analysis was used to quantify the internal consistency of the research instrument. Descriptive statistical analysis (frequencies, means, and standard deviations) was used to determine the respondents' demographic profile, tourist's expectations and perceptions of performance ("experience"), and the difference between tourist's expectations and perceptions of performance. Inferential analysis (paired samples t-test) was also used to determine the probability of difference between the tourist's expectations and performance scores.

\subsection{Reliability Statistics}

The Cronbach's alpha is one of the most commonly used measures of internal consistency (reliability) for research where we have used a Likert scale and wish to determine whether the scale is reliable. In order to study the internal consistency of the questionnaire and items, the Cronbach's alpha value and Cronbach's alpha coefficients if item deleted were calculated. The overall value of the Cronbach's alpha for the modified HOLSAT survey instrument comprising 41 items was 0.945 . Considering the alpha value was above 0.800 , it is suggested that the questionnaire has a good degree of internal consistency [48]. The Cronbach's alpha coefficients if item deleted range between 0.943 to 0.945 , and confirm that if we removed any of the items from the questionnaire it would result in a lower Cronbach's alpha. Therefore, it is suggested not to remove any items 
from the questionnaire. Overall, results suggest that the modified HOLSAT survey instrument comprising 41 items and used in this research, can be considered a reliable measure of tourist's perception of satisfaction with Fiji as a holiday destination.

\subsection{Demographic Profiling of Sample}

Demographic profiling of the 200 respondents (Table 3 ) shows that the majority were males ( $n=134,67.0$ percent) followed by females ( $n=66,33.0$ percent), and were predominantly in the age ranges of $26-35$ years ( $n=69,34.5$ percent), 18 - 25 years $(n=67,33.5$ percent), and $35-50$ years $(n=48,24.0$ percent). The

Table 3. Demographic profiling of respondents.

\begin{tabular}{|c|c|c|c|}
\hline Demographic Variables & Categories & Number & $\%$ \\
\hline \multirow[t]{2}{*}{ Gender } & Male & 134 & 67.0 \\
\hline & Female & 66 & 33.0 \\
\hline \multirow[t]{4}{*}{ Age (years) } & $18-25$ & 67 & 33.5 \\
\hline & $26-35$ & 69 & 34.5 \\
\hline & $36-50$ & 48 & 24.0 \\
\hline & Above 50 & 16 & 8.0 \\
\hline \multirow[t]{4}{*}{ Education } & High School & 7 & 3.5 \\
\hline & Certificate/Diploma & 22 & 11.0 \\
\hline & Undergraduate Degree & 146 & 73.0 \\
\hline & Postgraduate Degree & 25 & 12.5 \\
\hline \multirow[t]{2}{*}{ Marital Status } & Single & 67 & 33.5 \\
\hline & Married & 133 & 66.5 \\
\hline \multirow[t]{9}{*}{ Country of Origin } & Australia & 101 & 50.5 \\
\hline & New Zealand & 39 & 19.5 \\
\hline & US & 18 & 9.0 \\
\hline & Pacific Islands & 14 & 7.0 \\
\hline & China & 10 & 5.0 \\
\hline & Europe & 6 & 3.0 \\
\hline & UK & 4 & 2.0 \\
\hline & Canada & 4 & 2.0 \\
\hline & Asia & 4 & 2.0 \\
\hline \multirow[t]{2}{*}{ First-Time Visitor to Fiji } & Yes & 76 & 38.0 \\
\hline & No & 124 & 62.0 \\
\hline \multirow[t]{4}{*}{ Purpose of Visit } & Holiday & 131 & 65.5 \\
\hline & Business & 46 & 23.0 \\
\hline & Sports & 11 & 5.5 \\
\hline & Health & 12 & 6.0 \\
\hline
\end{tabular}


education level attained by respondents was primarily undergraduate degree ( $n$ $=146,73.0$ percent). Most respondents were married ( $n=133,66.5$ percent), and the dominant country of origin was either Australia ( $n=101,50.5$ percent) or New Zealand ( $n=39,19.5$ percent). For most of the respondents this was not their first visit to Fiji ( $n=124,62.0$ percent), and the primary purpose of their visit was for a holiday ( $n=131,65.5$ percent) or business ( $n=46,23.0$ percent).

\subsection{Positive Attributes of a Holiday Analysis}

Table 4 shows the positive attribute item mean score $(M)$ and standard deviation $(S D)$ for respondents' perceptions of performance ("experience") and expectations, the mean difference between perceptions of performance and expectations, and the paired-samples t-test results. Mean results show that perceptions of performance range between item 38 "I would be able to visit a Fijian village" $(M=2.30)$ and item 4 "The resort would be safe and secure" ( $M=3.66)$; and, the expectations range between item 17 "Transfer vehicle would be on-time and air conditioned" ( $M=2.18)$ and item 1 "The beaches and ocean would be clean" ( $M$ = 3.54). Standard deviation results for perceptions of performance range between item 11 "Shops would be cheap", item 22 "I would be able to sample local food and drink", and item 29 "Hotel staff would be friendly" ( $S D=0.81$ ), and item 38 "I would be able to visit a Fijian village) $(S D=2.26)$; and, the expectations range between item 1 "The beaches and ocean would be clean" and item 29 "Hotel staff would be friendly" ( $S D=0.87$ ) and item 9 "Restaurants would be cheap" ( $\mathrm{SD}=2.21$ ). These results suggest wide ranging variation in opinions of respondents in terms of perceptions of performance and expectations of the positive attributes of their holiday.

Paired-samples t-tests were conducted to compare perceptions of performance and expectations relating to the positive holiday attributes. Table 4 also shows that for 20 of the 31 positive holiday attributes (items 2, 4, 9 - 13, 16 - 17, $22-27,29,31,38-40$ ) there was a statistically significant difference in the scores for perceptions of performance and expectations $(p<0.05)$.

Of the 20 positive holiday attributes suggesting significant differences, 13 items showed statistically significant positive differences between perceptions of performance and expectations suggesting that respondents' expectations had been exceeded and they were delighted with the performance experienced: item 4 "The resort would be safe and secure: $t=2.76, p<0.05$; item 9 "Restaurants would be cheap" $t=3.05, p<0.05$; item 10 "Bars would be cheap" $t=2.56, p<$ 0.05 ; item 11 "Shops would be cheap" $t=2.81, p<0.05$; item 12 "Nightlife would be cheap" $t=2.29, p<0.05$; item 13 "Hotel meals would be of high quality" $t=$ 2.16, $p<0.05$; item 16 "The arrival airport would be modern and efficient" $t=$ 2.08, $p<0.05$; item 17 "Transfer vehicle would be on-time and air conditioned" $t$ $=2.03, p<0.05$; item 22 "I would be able to sample local food and drink" $t=$ $3.20, p<0.05$; item 25 "I would be able to shop in local markets" $t=2.31, p<$ 0.05 ; item 26 "I would be able to buy cheap Fijian artefacts" $t=2.27, p<0.05$; 
Table 4. Mean scores, mean difference and paired-sample t-test results-positive attributes of a holiday.

\begin{tabular}{|c|c|c|c|c|c|c|c|c|}
\hline \multirow[t]{2}{*}{ No. } & \multirow[t]{2}{*}{ Statement } & \multicolumn{2}{|c|}{ Expectations } & \multicolumn{2}{|c|}{ Performance } & \multirow{2}{*}{$\begin{array}{c}\text { Mean Difference } \\
\text { (Performance - } \\
\text { Expectations) }\end{array}$} & \multicolumn{2}{|c|}{ t-test ${ }^{*}$} \\
\hline & & Mean & SD & Mean & SD & & $\mathrm{t}$ & Sig. \\
\hline 1 & The beaches and ocean would be clean & 3.54 & 0.87 & 3.57 & 0.87 & 0.03 & 0.43 & 0.669 \\
\hline 2 & Check in and check times would be flexible & 3.44 & 1.06 & 3.05 & 0.87 & -0.39 & -2.44 & 0.015 \\
\hline 3 & The resort would be clean & 3.47 & 1.01 & 3.52 & 1.35 & 0.05 & 0.44 & 0.663 \\
\hline 4 & The resort would be safe and secure & 3.40 & 1.06 & 3.66 & 1.10 & 0.26 & 2.76 & 0.006 \\
\hline 5 & The resort would have a variety of restaurants & 3.10 & 1.20 & 3.21 & 1.70 & 0.11 & 0.95 & 0.345 \\
\hline 6 & The resort would have a variety of bars & 3.09 & 1.20 & 3.16 & 1.53 & 0.07 & 0.62 & 0.536 \\
\hline 7 & The resort would have a variety of shops & 3.04 & 1.30 & 3.14 & 1.53 & 0.10 & 0.83 & 0.409 \\
\hline 8 & The resort would have a variety of nightlife & 3.14 & 1.20 & 3.06 & 1.75 & -0.08 & -0.65 & 0.518 \\
\hline 9 & Restaurants would be cheap & 2.39 & 2.21 & 2.74 & 2.00 & 0.35 & 3.05 & 0.003 \\
\hline 10 & Bars would be cheap & 3.19 & 1.19 & 3.42 & 1.15 & 0.23 & 2.56 & 0.011 \\
\hline 11 & Shops would be cheap & 3.46 & 0.91 & 3.64 & 0.81 & 0.18 & 2.81 & 0.006 \\
\hline 12 & Nightlife would be cheap & 3.21 & 1.13 & 3.45 & 1.24 & 0.24 & 2.29 & 0.023 \\
\hline 13 & Hotel meals would be of high quality & 3.10 & 1.25 & 3.34 & 1.42 & 0.24 & 2.16 & 0.032 \\
\hline 15 & In-flight service would be high quality & 3.08 & 1.23 & 3.11 & 1.31 & 0.03 & 0.31 & 0.754 \\
\hline 16 & The arrival airport would be modern and efficient & 2.44 & 1.88 & 2.64 & 2.03 & 0.20 & 2.08 & 0.039 \\
\hline 17 & Transfer vehicle would be on-time and air conditioned & 2.18 & 2.01 & 2.39 & 1.86 & 0.21 & 2.03 & 0.044 \\
\hline 22 & I would be able to sample local food and drink & 3.38 & 1.01 & 3.59 & 0.81 & 0.21 & 3.20 & 0.002 \\
\hline 23 & Water sports would be available & 3.31 & 1.03 & 2.81 & 1.81 & -0.50 & -4.16 & 0.000 \\
\hline 24 & $\begin{array}{l}\text { I would be able to experience traditional Fijian singing and } \\
\text { dancing }\end{array}$ & 3.19 & 1.29 & 3.08 & 1.44 & -0.11 & -1.99 & 0.048 \\
\hline 25 & I would be able to shop in local markets & 3.11 & 1.40 & 3.34 & 1.21 & 0.23 & 2.31 & 0.022 \\
\hline 26 & I would be able to buy cheap Fijian artefacts & 3.12 & 1.15 & 3.34 & 1.36 & 0.22 & 2.27 & 0.024 \\
\hline 27 & I would be able to experience an island cruise & 3.08 & 1.18 & 3.29 & 1.28 & 0.22 & 2.09 & 0.038 \\
\hline 29 & Hotel staff would be friendly & 3.49 & 0.87 & 3.68 & 0.81 & 0.19 & 2.28 & 0.024 \\
\hline 30 & The room would be quiet & 3.49 & 0.90 & 3.50 & 1.17 & 0.01 & 0.12 & 0.908 \\
\hline 31 & The room would have a good view & 3.33 & 1.03 & 2.79 & 1.77 & -0.54 & -5.15 & 0.000 \\
\hline 32 & $\begin{array}{l}\text { The hotel and my room would have good internet } \\
\text { connectivity }\end{array}$ & 3.36 & 0.94 & 3.37 & 1.44 & 0.01 & 0.05 & 0.964 \\
\hline 33 & Facilities in the room would function properly & 3.30 & 1.23 & 3.27 & 1.53 & -0.03 & -0.31 & 0.757 \\
\hline 34 & The room would have a comfortable bed and clean bedding & 3.34 & 1.19 & 3.37 & 1.26 & 0.03 & 0.37 & 0.711 \\
\hline 38 & I would be able to visit a Fijian village & 2.80 & 1.90 & 2.30 & 2.26 & -0.50 & -6.07 & 0.000 \\
\hline 39 & I would be able to visit historical sites & 2.86 & 1.98 & 2.45 & 2.14 & -0.41 & -4.25 & 0.000 \\
\hline 40 & I would be able to visit a rainforest & 2.96 & 1.75 & 2.49 & 2.15 & -0.47 & -4.89 & 0.000 \\
\hline
\end{tabular}

*Bolded numbers show statistically significant t-test results.

item 27 "I would be able to experience an island cruise" $t=2.09, p<0.05$; item 29 "Hotel staff would be friendly" $t=2.28, p<0.05$. 
Of the 20 positive holiday attributes suggesting significant differences, 7 items showed statistically significant negative differences between perceptions of performance and expectations suggesting that respondents' expectations had not been met and they were dissatisfied with the performance experienced: item 2 "Check in and check out times would be flexible" $t=-2.44, p<0.05$; item 23 "Water sports would be available" $t=-4.16, p<0.05$; item 24 "I would be able to experience traditional Fijian singing and dancing" $t=-1.99, p<0.05$; item 31 "The room would have a good view" $t=-5.15, p<0.05$; item 38 "I would be able to visit a Fijian village" $t=-6.07, p<0.05$; item 39 "I would be able to visit historical sites" $t=-4.25, p<0.05$; and item 40 "I would be able to visit a rainforest" $t=-4.89, p<0.05$.

For the remaining 11 positive holiday attributes there was no significant difference in the respondents' scores for perceptions of performance and expectations $(p>0.05)$, suggesting that respondents' expectations had been sufficiently met/close to being met that they were satisfied: items 1 "The beaches and ocean would be clean" $t=0.43, p>0.05$; item 3 "The resort would be clean" $t=0.44$, $p>0.05$; item 5 "The resort would have a variety of restaurants" $t=0.95, \mathrm{p}>$ 0.05 ; item 6 "The resort would have a variety of bars" $t=0.62, p>0.05$; item 7 "The resort would have a variety of shops" $t=0.83, p>0.05$; item 8 "The resort would have a variety of nightlife" $t=-0.65, p>0.05$; item 15 "In-flight service would be high quality" $t=0.31, p>0.05$; item 30 "The room would be quiet" $t=$ $0.12, p>0.05$; item 32 "The hotel and my room would have good internet connectivity" $t=0.05, p>0.05$; item 33 "Facilities in the room would function properly" $t=-0.31, p>0.05$; and item 34 "The room would have a comfortable bed and clean bedding" $t=0.37, p>0.05$.

Figure 1 is a variant of the HOLSAT explanatory matrix for positive holiday attributes, with perception of performance (X-axis) plotted against expectations (Y-axis). In order to assist interpretation of the attribute item numbers detailed in Table 4, the attribute item numbers are plotted in the matrix and numbered data points result [16]. Figure 1 shows that the positive holiday attribute data points were predominantly closely clustered around the "draw" line indicating

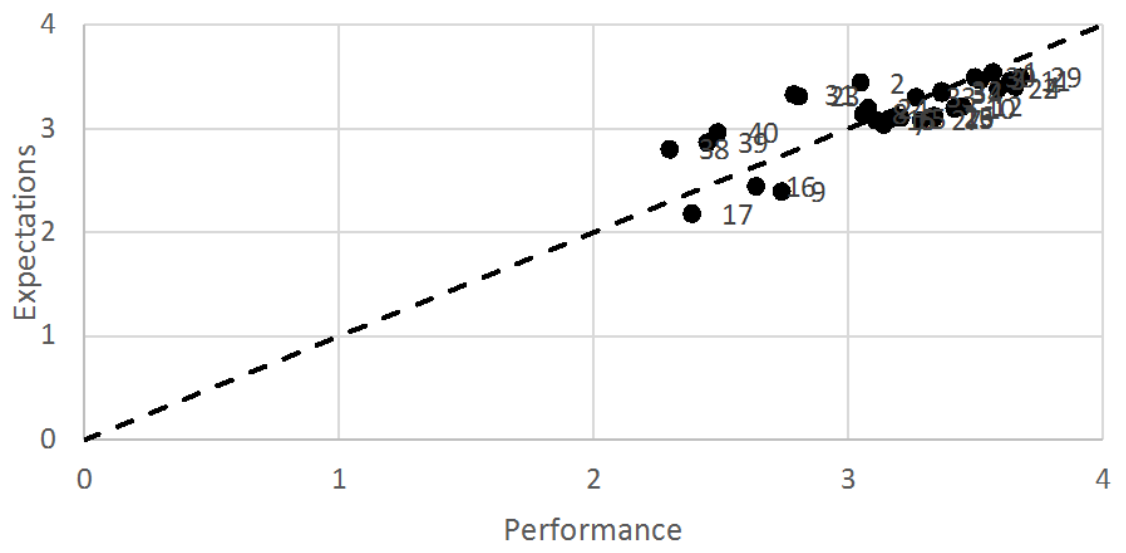

Figure 1. Performance/expectations matrix for positive attributes. 
tourist satisfaction, and tending below the "draw" line indicating a gain in satisfaction (tourist delight). Some data points were located above the "draw" line indicating a loss of satisfaction (tourist dissatisfaction).

\subsection{Negative Attributes of a Holiday Analysis}

[21] suggest that when interpreting the negative attributes of the HOLSAT model, where the difference between perceived performance and expectations is negative, it is an indication of tourist satisfaction. Conversely, positive differences are an indication of tourist dissatisfaction. Table 5 shows the negative attribute item mean score $(M)$ and standard deviation $(S D)$ for respondents' perceptions of performance ("experience") and expectations, the mean difference between perceptions of performance and expectations, and the paired-samples t-test results. Mean results show that perceptions of performance range between item 18 "I would have difficulty obtaining cash from my credit card or ATM" and item 37 "There might be power cuts" $(M=1.13)$, and item 19 "I would have to be careful what I eat and drink" $(M=3.75)$; and, the expectations range between item 18 "I would have difficulty obtaining cash from my credit card or $\operatorname{ATM"}(M=2.47)$ and item 19 "I would have to be careful what I eat and drink" $(M=3.51)$. Standard deviation results for perceptions of performance range between item 14 "There would be a lack of public toilet facilities" ( $S D=1.14$ ), and item 18 "I would have difficulty obtaining cash from my credit card or ATM" $(S D=2.36)$; and, the expectations range between item 21 "Immigration and customs clearance would be slow and inefficient" and item 41 "There would be pollution in the towns and cities" ( $S D=1.03)$, and item 18 "I would have difficulty obtaining cash from my credit card or ATM" $(S D=1.69)$. While these results

Table 5. Mean scores, mean difference and paired-sample t-test results-negative attributes of a holiday.

\begin{tabular}{|c|c|c|c|c|c|c|c|c|}
\hline \multirow[t]{2}{*}{ No. } & \multirow[t]{2}{*}{ Statement } & \multicolumn{2}{|c|}{ Expectations } & \multicolumn{2}{|c|}{ Performance } & \multirow{2}{*}{$\begin{array}{c}\text { Mean Difference } \\
\text { (Perceptions - } \\
\text { Expectations) }\end{array}$} & \multicolumn{2}{|c|}{ t-test ${ }^{*}$} \\
\hline & & Mean & $\mathrm{SD}$ & Mean & $\mathrm{SD}$ & & $\mathrm{t}$ & Sig. \\
\hline 14 & There would be a lack of public toilet facilities & 3.02 & 1.59 & 3.44 & 1.14 & 0.42 & 3.43 & 0.001 \\
\hline 18 & $\begin{array}{l}\text { I would have difficulty obtaining cash from my } \\
\text { credit card or ATM }\end{array}$ & 2.47 & 1.69 & 1.13 & 2.36 & -1.34 & -10.13 & 0.000 \\
\hline 19 & I would have to be careful what I eat and drink & 3.51 & 1.07 & 3.75 & 1.24 & 0.24 & 2.54 & 0.012 \\
\hline 20 & Changing money would be difficult & 2.65 & 1.51 & 2.38 & 2.06 & -0.27 & -2.92 & 0.004 \\
\hline 21 & $\begin{array}{l}\text { Immigration and customs clearance would be slow } \\
\text { and inefficient }\end{array}$ & 3.33 & 1.03 & 1.49 & 2.12 & -1.84 & -10.99 & 0.000 \\
\hline 28 & There would be many beggars and street vendors & 2.86 & 1.51 & 1.86 & 2.16 & -1.00 & -8.96 & 0.000 \\
\hline 35 & There might be shortages of some food and drink & 2.90 & 1.50 & 2.34 & 2.04 & -0.56 & -5.58 & 0.000 \\
\hline 36 & There might be shortages of fresh water & 3.09 & 1.42 & 2.39 & 2.18 & -0.70 & -6.61 & 0.000 \\
\hline 37 & There might be power cuts & 2.71 & 1.66 & 1.13 & 2.22 & -1.58 & -11.17 & 0.000 \\
\hline 41 & There would be pollution in the towns and cities & 3.33 & 1.03 & 2.15 & 1.92 & -1.18 & -8.81 & 0.000 \\
\hline
\end{tabular}

*Bolded numbers show statistically significant t-test results. 
also suggest some variation in opinions of respondents in terms of perceptions of performance and expectations of negative holiday attributes, the variation in opinions is less than for the perceptions of performance and expectations of positive holiday attributes.

Paired-samples t-tests were conducted to compare perceptions of performance and expectations relating to the negative holiday attributes. Table 5 also shows that for all the negative holiday attributes (items 14, 18 - 21, 28, 35 - 37, and 41) there was a statistically significant difference in the scores for perceptions of performance and expectations $(p<0.05)$.

Of the 10 negative holiday attributes suggesting statistically significant differences, 2 items showed statistically significant positive differences between perceptions of performance and expectations suggesting that respondents' negative expectations had been exceeded: item 14 "There would be a lack of public toilet facilities" $t=3.43, p<0.05$; and item 19 "I would have to be careful what I eat and drink" $t=2.54, p<0.05$..

Of the 10 negative holiday attributes suggesting significant differences, 8 items showed statistically significant negative differences between perceptions of performance and expectations suggesting that respondents' negative expectations had not been realised: item 18 "I would have difficulty obtaining cash from my credit card or ATM" $t=-10.13, p<0.05$; item 20 "Changing money would be difficult" $t=-2.92, p<0.05$; item 21 "Immigration and customs clearance would be slow and inefficient" $t=-10.99, p<0.05$; item 28 "There would be many beggars and street vendors" $t=-8.96, p<0.05$; item 35 "There might be shortages of some food and drink" $t=-5.58, p<0.05$; item 36 "There might be shortages of fresh water" $t=-6.61, p<0.05$, item 37 “There might be power cuts" $t=-11.17, p>0.05$; and item 41 "There would be pollution in the towns and cities" $t=-8.81, p<0.05$.

Figure 2 is a variant of the HOLSAT explanatory matrix for negative attributes, with perception of performance (X-axis) plotted against expectations (Y-axis). In order to assist interpretation of the attribute item numbers detailed in Table 5, the attribute item numbers are plotted in the matrix and numbered data points result [16].

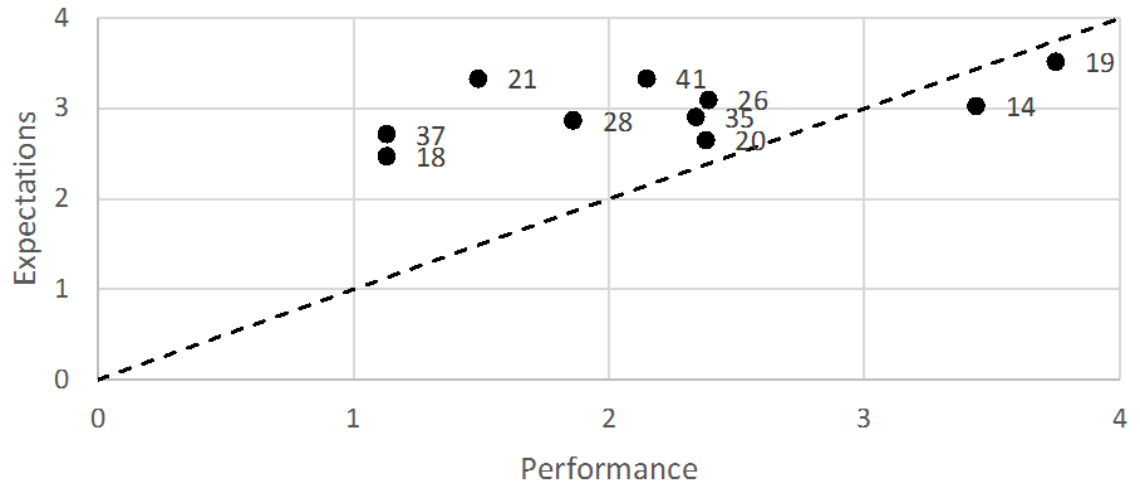

Figure 2. Performance/expectations matrix for negative attributes. 
Figure 2 shows that 8 of 10 negative holiday attribute data points were dispersed above the "draw" line indicating a gain in satisfaction (tourist delight), with only 2 data points below the "draw" line indicating a loss of satisfaction (tourist dissatisfaction).

\section{Conclusions}

For this research the modified HOLSAT questionnaire has shown to have a good degree of internal consistency. This would suggest that the questionnaire and holiday attribute items administered are fit for purpose in measuring international tourist's satisfaction (in terms of expectations and experiences) with Fiji as a holiday destination. Holiday satisfaction analysis results revealed that 24 of the 31 (77 percent) of positive attribute items of a holiday exceeded or met tourist's expectations, and 8 of the 10 (80 percent) negative attribute items of a holiday were below tourist's expectations, therein both contributed to tourist's sense of satisfaction with the holiday destination. Holiday attribute items that failed to satisfy tourists provide opportunities for targeted interventions to further enhance tourist's satisfaction with Fiji as a holiday destination.

The demographic profiling of the sampled tourists is also significant, and at the same time concerning, in that it highlights the heavy reliance of Fiji tourism on two traditional source markets, namely Australia and New Zealand [1] [49]. Any downturn or volatility in these two economies could have serious ramifications on Fiji visitor arrivals [1]. Overlaying these findings with volatility and declining tourist visitor arrivals from distanced markets only further reinforces the need for policy makers, travel agencies and marketing decision makers to implement strategies to target non-traditional markets, ensure price competitiveness comparable to competitors, mitigate the negative effects of distance [1], and promote and deliver the specific holiday attributes needed to ensure that tourists continue to perceive Fiji to be a competitive, preferred holiday destination.

This study's theoretical contribution is to the scant knowledge that exists regarding tourist satisfaction research of small island developing nation holiday destinations such as Fiji. The practical contribution of this research is that it informs policy makers, tourism agencies and marketing decision makers of the specific holiday destination attribute items needed to be offered to satisfy tourists, and the need for targeted interventions to address holiday attribute items that failed to satisfy tourists. This research also cautions regarding the need to target non-traditional markets for tourists in order to diversify sources of tourist arrivals.

Limitations and opportunities for future research are derived from this study. Firstly, [21] the creators of the HOLSAT questionnaire suggested that "future studies should use a tripartite approach" when sampling, that is, before the holiday (expectations), during the holiday (performance measure 1) and after their return home (performance measure 2). It is suggested that such an approach would be difficult to implement. In this research, respondents were simply re- 
quested to provide responses of their expectations and performance ("experience") during their holiday in Fiji. Future research could investigate the practicality of the tripartite approach. Secondly, [21] suggested that their HOLSAT survey questionnaire was too lengthy, comprising 56 attributes, and took respondents too long to complete. To mitigate this limitation, this research reduced the number of attribute items to 41 . Future research could consider further reduction in the number of attribute items. Finally, considering "the difficulty in capturing an audience which is constantly shifting across geographical as well as service boundaries" [21], and that this research was cross-sectional in nature, it is suggested that this research be replicated, in order to determine any changes in the sources of international tourists and in satisfaction with Fiji as a holiday destination.

\section{Conflicts of Interest}

The author declares no conflicts of interest regarding the publication of this paper.

\section{References}

[1] Wainiqolo, I. and Shivanjali, S. (2018) Modelling Fiji's Tourism Arrivals. Economics Group Working Paper, Reserve Bank of Fiji, Suva. https://www.rbf.gov.fj/getattachment/Publications-(1)/Working-Papers/Reserve-Ba nk-of-Fiji-Working-Papers/Modelling-Fiji-s-Tourism-Arrivals.pdf?lang=en-US

[2] United Nations World Tourism Organisation (2018) 2017 International Tourism Results: The Highest in Seven Years. Press Release No. 18003.

http://media.unwto.org/press-release/2018-01-15/2017-international-tourism-result s-highest-seven-years

[3] Fiji Government (2018) Fiji Bureau of Statistics Releases 2017 Census Results. https://www.fiji.gov.fj/Media-Centre/News/Fiji-Bureau-of-Statistics-Releases-2017Census-Res

[4] Rubin, S.D., Lee, W., Paris, C.M. and Teye, V. (2016) The Influence of Mindfulness on Tourists' Emotions, Satisfaction and Destination Loyalty in Fiji. Travel and Tourism Research Association: Advancing Tourism Research Globally, 54. https://scholarworks.umass.edu/ttra/2011/Visual/54

[5] Ceylan, C. and Ozcelik, A.B. (2016) A Circular Approach to SERVQUAL and HOLSAT: An Implementation Suggestion. Journal of Hotel \& Business Management, 5, 1-10. https://doi.org/10.4172/2169-0286.1000125

[6] Kang, M.H., Gretzel, U. and Jamal, T. (2008) Mindfulness: Definitions and Development of a Measurement Scale. Proceedings of the 39th International Conference Extended Abstracts on Travel and Tourism Research Association, Philadelphia, PA.

[7] Yu, Y.T. and Dean, A. (2001) The Contribution of Emotional Satisfaction to Consumer Loyalty. International Journal of Service Industry Management, 12, 234-250. https://doi.org/10.1108/09564230110393239

[8] Yuksel, A. and Yuksel, F. (2001) Comparative Performance Analysis: Tourists' Perceptions of Turkey Relative to Other Tourist Destinations. Journal of Vacation Marketing, 7, 333-355. https://doi.org/10.1177/135676670100700404

[9] Meng, F., Tepanon, Y. and Uysal, M. (2008) Measuring Tourist Satisfaction by 
Attributes and Motivation: The Case of a Nature-Based Resort. Journal of Vacation Marketing, 14, 41-56. https://doi.org/10.1177/1356766707084218

[10] Yuksel, A. and Yuksel, F. (2003) Measurement of Tourist Satisfaction with Restaurant Services: A Segment-Based Approach. Journal of Vacation Marketing, 9, 52-68. https://doi.org/10.1177/135676670200900104

[11] Reisinger, Y. and Waryszak, R. (1995) Japanese Tourists' Perceptions of Their Tour Guides: Australian Experience. Journal of Vacation Marketing, 1, 28-40. https://doi.org/10.1177/135676679400100103

[12] Dunn Ross, E.L. and Iso-Ahola, S.E. (1991) Sightseeing Tourists' Motivation and Satisfaction. Annals of Tourism Research, 18, 226-237. https://doi.org/10.1016/0160-7383(91)90006-W

[13] Chen, C.-F. and Chen, F.S. (2010) Experience Quality, Perceived Value, Satisfaction and Behavioral Intentions for Heritage Tourists. Tourism Management, 31, 29-35. https://doi.org/10.1016/j.tourman.2009.02.008

[14] Malodia, S. and Singla, H. (2017) Using HOLSAT to Evaluate Satisfaction of Religious Tourist at Sacred Destinations: The Case of Religious Travelers Visiting Sacred Destinations in the Himalayas, India. International Journal of Culture, Tourism and Hospitality Research, 11, 255-270. https://doi.org/10.1108/IJCTHR-10-2015-0120

[15] Sukiman, M.F., Omar, S.I., Muhibudin, M., Yussof, I. and Mohamed, B. (2013) Tourist Satisfaction as the Key to Destination Survival in Pahang. Procedia-Social and Behavioral Sciences, 91, 78-87. https://doi.org/10.1016/j.sbspro.2013.08.404

[16] Truong, T.-H. and Foster, D. (2006) Using HOLSAT to Evaluate Tourist Satisfaction at Destinations: The Case of Australian Holidaymakers in Vietnam. Tourism Management, 27, 842-855. https://doi.org/10.1016/j.tourman.2005.05.008

[17] Hui, T.K., Wan, D. and Ho, A. (2007) Tourists' Satisfaction, Recommendation and Revisiting Singapore. Tourism Management, 28, 965-975. https://doi.org/10.1016/j.tourman.2006.08.008

[18] Yu, L. and Goulden, L.M. (2006) A Comparative Analysis of International Tourists' Satisfaction in Mongolia. Tourism Management, 27, 1331-1342. https://doi.org/10.1016/j.tourman.2005.06.003

[19] Harrison, D. and Prasad, B. (2013) The Contribution of Tourism to the Development of Fiji and Other Pacific Island Countries. In: Tisdell, C., Ed., Handbook of Tourism Economics-Analysis, New Applications and Case Studies, World Scientific Publishing, Singapore, 741-761. https://doi.org/10.1142/9789814327084_0032

[20] King, B. and Weaver, S. (1993) The Impact of the Environment on the Fiji Tourism Industry: A Study of Industry Attitudes. Journal of Sustainable Tourism, 1, 97-111. https://doi.org/10.1080/09669589309450708

[21] Tribe, J. and Snaith, T. (1998) From SERVQUAL to HOLSAT: Holiday in Varadero, Cuba. Tourism Management, 19, 25-34. https://doi.org/10.1016/S0261-5177(97)00094-0

[22] Giese, J.L. and Cote, J.A. (2002) Defining Consumer Satisfaction. Academy of Marketing Science Review, 1, 1-27.

[23] Parker, C. and Mathews, B.P. (2001) Customer Satisfaction: Contrasting Academic and Consumers' Interpretations. Marketing Intelligence \& Planning, 19, 38-44. https://doi.org/10.1108/02634500110363790

[24] Gardial, S., Fisher, D., Clemons, S., Woodruff, R.B., Schumann, D.W. and Burns, M.J. (1994) Comparing Consumers' Recall of Prepurchase and Postpurchase Prod- 
uct Evaluation Experiences. Journal of Consumer Research, 20, 548-560. https://doi.org/10.1086/209369

[25] Peterson, R.A. and Wilson, W.R. (1992) Measuring Customer Satisfaction: Fact and Artefact. Journal of the Academy of Marketing Science, 20, 61-71. https://doi.org/10.1007/BF02723476

[26] Kozak, M. (2002) Destination Benchmarking. Annals of Tourism Research, 29, 497-519. https://doi.org/10.1016/S0160-7383(01)00072-X

[27] Wu, L., Zhang, J. and Fujiwaraa, A. (2012) A Tourists' Multi-Destination Choice Model with Future Dependency. Asia Pacific Journal of Tourism Research, 17, 121-132. https://doi.org/10.1080/10941665.2011.616902

[28] Chang, K.C. (2012) Examining the Effect of Tour Guide Performance, Tourist Trust, Tourist Satisfaction, and Flow Experience on Tourists' Shopping Behavior. Asia Pacific Journal of Tourism Research, 19, 219-247. https://doi.org/10.1080/10941665.2012.739189

[29] Craggs, R. and Schofield, P. (2011) The Quays in SALFORD: An Analysis of Visitor Perceptions, Satisfaction and Behavioral Intention. International Journal of Tourism Research, 13, 583-599. https://doi.org/10.1002/jtr.831

[30] Denstadli, J.M. and Jacobsen, J.K.S. (2011) The Long and Winding Roads: Perceived Quality of Scenic Tourism Routes. Tourism Management, 32, 780-789. https://doi.org/10.1016/j.tourman.2010.06.014

[31] Zabkar, V., Brencic, M.M. and Dmitrovic, T. (2010) Modeling Perceived Quality, Visitor Satisfaction and Behavioural Intentions at the Destination Level. Tourism Management, 31, 537-546. https://doi.org/10.1016/j.tourman.2009.06.005

[32] Reisinger, Y. and Turner, L. (2000) Japanese Tourism Satisfaction: Gold Coast versus Hawaii. Journal of Vacation Marketing, 6, 299-317. https://doi.org/10.1177/135676670000600402

[33] Ritchie, J.R.B. and Crouch, G.I. (2003) The Competitive Destination: A Sustainable Tourism Perspective. CABI Publishing, Wallingford.

[34] Khadaroo, J. and Seetanah, B. (2008) The Role of Transport Infrastructure in International Tourism Development: A Gravity Model Approach. Tourism Management, 29, 831-840. https://doi.org/10.1016/j.tourman.2007.09.005

[35] Rosentraub, M.S. and Joo, M. (2009) Tourism and Economic Development: Which Investments Produce Gains for Regions? Tourism Management, 30, 759-770. https://doi.org/10.1016/j.tourman.2008.11.014

[36] Martilla, J. and James, J. (1997) Importance-Performance Analysis. Journal of Marketing, 41, 77-79. https://doi.org/10.1177/002224297704100112

[37] Parasuraman, A., Berry, L.L. and Zeithaml, V.A. (1988) SERVQUAL: A Multiple-Item Scale for Measuring Consumer Perceptions of Service Quality. Journal of Retailing, 4, 12-37.

[38] Cronin, J.J. and Taylor, S.A. (1994) SERVPERF versus SERVQUAL: Reconciling Performance-Based and Perceptions-Minus-Expectations Measurement of Service Quality. Journal of Marketing, 58, 125-131. https://doi.org/10.1177/002224299405800110

[39] Oliver, R.A. (1980) A Cognitive Model of the Antecedents and Consequences of Satisfaction Decisions. Journal of Marketing Research, 17, 460-469. https://doi.org/10.1177/002224378001700405

[40] Churchill, G.A. and Surprenant, C. (1982) An Investigation into the Determinants of Customer Satisfaction. Journal of Marketing Research, 19, 491-504. 
https://doi.org/10.1177/002224378201900410

[41] Parasuraman, A. and Berry, L.L. (1991) Refinement and Reassessment of the SERVQUAL Scale. Journal of Retailing, 67, 421-450.

[42] Danaher, P.J. and Arweiler, N. (1996) Customer Satisfaction in the Tourist Industry: A Case Study of Visitors to New Zealand. Journal of Travel Research, 31, 89-93. https://doi.org/10.1177/004728759603500113

[43] Knutson, B.J., Stevens, P. and Patton, M. (1995) DINESERV: Measuring Service Quality in Quick Service, Casual/Theme and Fine Dine Restaurants. Journal of Hospitality and Leisure Marketing, 3, 35-44. https://doi.org/10.1300/J150v03n02_04

[44] Qu, H. and Li, I. (1997) The Characteristics and Satisfaction of Mainland Chinese Visitors to Hong Kong. Journal of Travel Research, 35, 37-41. https://doi.org/10.1177/004728759703500406

[45] Kozak, M. and Rimmington, M. (2000) Tourist Satisfaction with Mallorca, Spain, as an Off-Season Holiday Destination. Journal of Travel Research, 38, 260-269. https://doi.org/10.1177/004728750003800308

[46] Meimand, S.E., Khalifah, Z. and Hakemi, H.G. (2013) Expectation and Experience Gap for Japanese Travellers Visiting Malaysian Homestay, Utilising Holiday Satisfaction Model. Indian Journal of Science and Technology, 6, 5593-5599.

[47] Ryan, C. (1999) From Psychometrics to SERVQUAL to Sex: Measurement of Tourist Satisfaction. In: Pizam, A. and Mansfield, Y., Eds., Consumer Behavior in Travel and Tourism, The Haworth Press, New York.

[48] Hair, J.F., Black, W.C., Babin, B.J., Anderson, R.E. and Tatham, R.L. (2006) Multivariant Data Analysis. Pearson University Press, Upper Saddle River, NJ.

[49] Pareti, S.V. (2015) The Chinese Are Coming-Is Fiji Ready? A Study of Chinese Tourists to Fiji. Pacific Studies, 34, 145-165. 